\title{
Water resource management for sustainable development
}

\author{
Ali Sdiri ${ }^{1} \cdot$ José Pinho $^{2} \cdot$ Chavalit Ratanatamskul $^{3}$ \\ Received: 19 January 2018 / Accepted: 22 January 2018 / Published online: 20 March 2018 \\ (C) Saudi Society for Geosciences 2018
}

Water resource management is the cornerstone for sustainable development. According to the United Nations world water development report, one-fifth of the world's population lives in areas characterized by physical water scarcity (Xu et al. 2018). The increase of water demand concomitantly with water scarcity is a common threat for humanity; it is expected to be worse in the future. Almost half of the world population will be living in area with high water stress by 2030 (United Nation Department of Economic and Social Affairs 2012). Thus, potential water resources need to be monitored with care for strategic management. Population growth and economic development cause significant increase in agricultural and industrial demand for water. Recently, Guerra and Reklaitis (2018) addressed the growing vulnerability to both availability and quality of water sources. They stated that "the vulnerability of energy systems to water utilization constraints could be mitigated by the effective design and implementation of water management strategies." This was consistent with main target of the $2^{\text {nd }}$ International Conference on Integrated Environmental Management for Sustainable Development (ICIEM), held in Sousse-Tunisia from 27 to 30 October 2016 because water management issues require more attention

This article is part of the Topical Collection on Water Resource Management for Sustainable Development

Ali Sdiri

ali.sdiri@enis.rnu.tn

José Pinho

jpinho@ civil.uminho.pt

$\triangle$ Chavalit Ratanatamskul dr_chawalit@yahoo.com

1 National Engineering School, University of Sfax, P. Box 1173-3038, Sfax, Tunisia

2 Centre for Territory, Environment and Construction, University of Minho, Braga, Portugal

3 Faculty of Engineering, Chulalongkorn University, Bangkok, Thailand by the research community, especially in arid/semi-arid countries.

The integration of wastewater quality and vulnerability into the design and planning of water management strategies are needed. Numerous researchers have addressed the strategic topic of water resource management, especially for agriculture (Al-Saidi 2017; Christ and Burritt 2017; Gao et al. 2017; Liu et al. 2017; Nguyen et al. 2018; Ross 2017; Skouteris et al. 2018; Zhou et al. 2017). It is well known the agriculture accounts for more than two thirds of the global water use (Kraiem et al. 2014). This situation may induce severe water crisis and all waters even those of bad quality have to be valued and stored. Therefore, integrated water management is one of the pillars of sustainable development. In this context, the $2^{\text {nd }}$ ICIEM conference aimed at exchanging relevant experiences, up-to-date scientific research, and findings carried out all over the world to protect and preserve the environment through rationalizing water resources. More than 300 participants attended this event to share new findings and discuss the potential applications of such new processes that can be turned out to viable technique for sustainable development. This thematic issue includes selected papers from the conference acting in the field of water resources. They have, undoubtedly, contributed to deepen knowledge on the current researches and achievements in the broad field of water resources. The main aspects are the following: water quality and sustainable use, integrated water resources management, assessment of groundwater vulnerability, the quantity and quality of water streams, the potential for the treatment of these waters for recycle and/or beneficial reuse and the economics of such treatment strategies and management of irrigation water and durability.

Fruitful exchange between researchers during the conference alongside the peer review process clearly showed their common concern to address the problem of water management for the sake of sustainable development. Few problems may be specific to a given region, but similarity in the diagnosis as well as the remediation approaches demonstrated that 
the scientific community should bring solutions for sustainable water resources management.

Beyond the presented results, our meeting was a great occasion for launching new collaborative actions and new networks to better face the challenges and handle the risks for our resources and human being. Therefore, we are grateful for researchers who attended this edition of ICIEM.

During the review process, a thorough evaluation of selected manuscripts was necessary to meet high scientific standards. Only scientifically sound papers were selected for inclusion in this thematic issue. We are thankful to all scientists who actively contributed to the success of the meeting, hoping that there will be other occasions to meet and exchange ideas and new scientific results. We also would like to congratulate the authors of this thematic collection. Special thanks go to the reviewers who effectively contributed to this achievement.

\section{References}

Al-Saidi M (2017) Conflicts and security in integrated water resources management. Environ Sci Pol 73:38-44. https://doi.org/10.1016/j. envsci.2017.03.015

Christ KL, Burritt RL (2017) Water management accounting: a framework for corporate practice. J Clean Prod 152:379-386. https://doi. org/10.1016/j.jclepro.2017.03.147

Gao L, Bryan BA, Liu J, Li W, Chen Y, Liu R, Barrett D (2017) Managing too little and too much water: robust mine-water manage- ment strategies under variable climate and mine conditions. J Clean Prod 162:1009-1020. https://doi.org/10.1016/j.jclepro.2017.06.101

Guerra OJ, Reklaitis GV (2018) Advances and challenges in water management within energy systems. Renew Sust Energ Rev 82:40094019. https://doi.org/10.1016/J.RSER.2017.10.071

Kraiem Z, Zouari K, Chkir N, Agoune A (2014) Geochemical characteristics of arid shallow aquifers in Chott Djerid, south-western Tunisia. J Hydro Environ Res 8(4):460-473. https://doi.org/10. 1016/j.jher.2013.06.002

Liu R, Wei T, Zhao Y, Wang Y (2017) Presentation and perspective of appealing Green Facilities for eco-cyclic water management. Chem Eng J. https://doi.org/10.1016/j.cej.2017.12.127

Nguyen KA, Stewart RA, Zhang H, Sahin O, Siriwardene N (2018) Reengineering traditional urban water management practices with smart metering and informatics. Environ Model Softw 101:256267. https://doi.org/10.1016/j.envsoft.2017.12.015

Ross A (2017) Speeding the transition towards integrated groundwater and surface water management in Australia. J Hydrol. https://doi. org/10.1016/j.jhydrol.2017.01.037

Skouteris G, Ouki S, Foo D, Saroj D, Altini M, Melidis P, Cowley B, Ells G, Palmer S, O'Dell S (2018) Water footprint and water pinch analysis techniques for sustainable water management in the brickmanufacturing industry. J Clean Prod 172:786-794. https://doi.org/ 10.1016/j.jclepro.2017.10.213

United Nation Department of Economic and Social Affairs (2012) "Water for Life" 2005-2015: Water scarcity [WWW Document]. URL http:// www.un.org/waterforlifedecade/scarcity.shtml (accessed 1.8.18)

Xu Q, Qiang Z, Chen Q, Liu K, Cao N (2018) A superposed model for the pipe failure assessment of water distribution networks and uncertainty analysis: a case study. Water Resour Manage 32:1713. https:// doi.org/10.1007/s11269-017-1899-8

Zhou X, Li Y, Lai F (2017) Effects of different water management on absorption and accumulation of selenium in rice. Saudi J Biol Sci. https://doi.org/10.1016/j.sjbs.2017.10.017 